\title{
Mechanical Properties of the Fiber Cell Wall in Bambusa pervariabilis Bamboo and Analyses of Their Influencing Factors
}

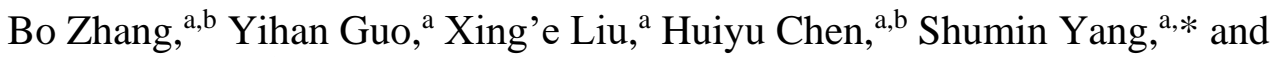
Yan'gao Wang ${ }^{b}$

The cell wall mechanical properties are an important indicator for evaluating the overall mechanical properties of natural bamboo fibers. Using the nanoindentation technique, the variation of the mechanical properties of the fiber cell wall of Bambusa pervariabilis culms with different ages and different positions (both radial and longitudinal) was studied. Moreover, $x$-ray diffraction (XRD) was employed to measure the microfibril angle (MFA), and the correlation between the MFA and the mechanical properties of the fiber cell wall. The results showed that there was a remarkable difference in the fiber cell wall mechanical properties at different ages and at different radial and longitudinal positions. However, at different ages and at different positions, the absolute value of variation of MFA was less than $1^{\circ}$ and was very minor. Furthermore, there was no significant correlation between the fiber cell wall mechanics and MFA, indicating that the mechanical property of the fiber cell walls might be synergistically affected by many factors.

Keywords: Bambusa pervariabilis; Nanoindentation technique; NI modulus; NI hardness; MFA

Contact information: a: Key Lab of Bamboo and Rattan Science \& Technology, International Centre for Bamboo and Rattan, Beijing 100102, China; b: College of Forestry, Sichuan Agricultural University, Chengdu 611130, China;*Corresponding author: yangsm@icbr.ac.cn

\section{INTRODUCTION}

The bamboo plant typically has a rapid growth rate and a strong capacity for renewal. The mechanical property of bamboo can reach a stable state in a short period. It also has the advantages of high strength, ductility, and hardness (Wang et al. 2014; Huang and Fei 2017). Natural bamboo fiber is the major component of bamboo and largely contributes to the excellent mechanical properties of bamboo (Lo et al. 2004; Castanet et al. 2016; Sukmawan et al. 2016). The properties are often used as a reference model for biomimetic composite design due to the multi-layer cell wall structure (Huang et al. 2016; Kumar et al. 2017; Gupta and Singh 2018).

The bamboo fiber cell wall can be regarded as a natural composite material composed of hemicellulose and lignin, which function as the matrix phase. The microfibrils composed of cellulose serve as the reinforcing phase. It is known that the fiber cell wall is the main supporting structure of bamboo (Hu et al. 2017). The mechanical property of fiber cell walls is an important indicator for evaluating the essence of the complex macromechanical behavior of bamboo. However, due to the small size of the cell walls, it is impossible to quantitatively characterize the mechanical properties using conventional testing methods. In the $1990 \mathrm{~s}$, the nanoindentation technique was first used to quantitatively characterize the mechanical properties of the cell wall (Wimmer et al. 1997). 
Since then, nanoindentation technology has been applied to study the cell walls of bamboo fiber (Yu et al. 2007, 2011; Wang et al. 2012; Ren et al. 2017), and it has become an important method to characterize the mechanical properties of bamboo cell walls. To distinguish them from other mechanical indicators, some research refers to the elastic modulus and hardness obtained by the nanoindentation test as nanoindentation modulus (NI modulus) and nanoindentation hardness (NI hardness), respectively (Tian 2015; Huang et al. 2016).

In addition to the influence of external habitat conditions, the mechanical properties of fiber cell walls are also influenced by the structural characterization of major chemical components such as cellulose, hemicellulose, and lignin, as well as their distribution and inter-linkages (Konnerth et al. 2009; Zou et al. 2009). In regard to cell wall structure and microfibril orientation, even a nanoindentation test with embedded or non-embedded samples can introduce differences in mechanical properties of fiber cell walls (Bourmaud et al. 2013; Meng et al. 2013). The view that microfibril angle (MFA) is a key factor largely determining the mechanical properties of bamboo and wood fibers has been confirmed by many reports (Tze et al. 2007; Krauss et al. 2011). The MFA is negatively correlated with the NI modulus and cell wall hardness (Liu 2008; Konnerth et al. 2009).

Bambusa pervariabilis is sympodial bamboo that primarily grows in southeast China. Its culm is solid and straight, so it is often used for making scaffolds, tools, furniture, and other weaving products in traditional industries. Now B. pervariabilis culms have been widely used in a variety of papermaking, textiles, composite materials, and nano materials. It is a favorable supplement to the typically used monopodial bamboo. Many studies have shown that the fiber in sympodial bamboo has favorable mechanical properties; however, there is little research concerning $B$. pervariabilis. The purpose of this research is to study the variation of mechanical properties of developmental B. pervariabilis fiber cell walls and to analyze its correlation with MFA. In this study, 1-, 2-, and 3-year-old $B$. pervariabilis culms were investigated using the nanoindentation and X-ray diffraction techniques. In addition, the variation of fiber cell walls mechanical properties and MFA with different ages and different positions (both radial and longitudinal) of the bamboo culms were studied. The correlation between the MFA and the mechanical properties of the cell wall fibers was analyzed. The results of this paper will provide a theoretical basis for bamboo plantation and rational processing and fine utilization of $B$. pervariabilis fibers.

\section{EXPERIMENTAL}

\section{Materials}

The tested bamboo species were collected from the Arboretum of the Guangxi Academy of Forestry, Guangxi province. The representative bamboo culms with typical normal growth were cut down. The diameter, internode length, and height of the bamboo were recorded. Bamboo sections were taken every $2 \mathrm{~m}$ (cut near a complete bamboo node) until a height of $7.5 \mathrm{~m}$ was reached from the base to the top of culm. Small bamboo blocks of $10 \mathrm{~mm}$ (longitudinal, L) by $5 \mathrm{~mm}$ (tangential, T) by $\mathrm{t} \mathrm{mm}$ (radial thickness, R) were also cut at the central from the $6^{\text {th }}, 12^{\text {th }}$, and $18^{\text {th }}$ internodes from bamboo culms of different ages (Table 1). All blocks were placed in an FAA fixative solution (5\% formaldehyde, $5 \%$ acetic acid, and $90 \%$ alcohol) for the subsequent determination of cell wall mechanical properties (Fig. 1). All samples were transported to the laboratory and stored at room temperature until processing was completed. To test the fiber cell wall mechanics and MFA 
variation in bamboo at different ages, the blocks at the middle position at the 6th internode of the 1-, 2-, and 3-year-old culms were used. The $6^{\text {th }}$ internode from 3-year-old culms were used to research radial variation. The $6^{\text {th }}, 12^{\text {th }}$, and $18^{\text {th }}$ internode from 3 -year-old bamboo were used to study the longitudinal variation (Table 1).

Table 1. Sampling Methods for Fiber Cell Wall Mechanical Properties and the MFA Test

\begin{tabular}{|c|c|c|c|}
\hline Variation Factors & Age/year & Radial Position & Longitudinal Position \\
\hline Bamboo age & $1,2,3$ & Middle position & $\begin{array}{c}\text { Central part of the 6th } \\
\text { internode }\end{array}$ \\
\hline Radial position & 3 & $\begin{array}{c}\text { Outer, middle, and } \\
\text { inner positions }\end{array}$ & $\begin{array}{c}\text { Central part of the 6th } \\
\text { internode }\end{array}$ \\
\hline $\begin{array}{c}\text { Longitudinal } \\
\text { position }\end{array}$ & 3 & Middle position & $\begin{array}{c}\text { Central parts of the 6th, 12th, } \\
\text { and 18th internode }\end{array}$ \\
\hline
\end{tabular}

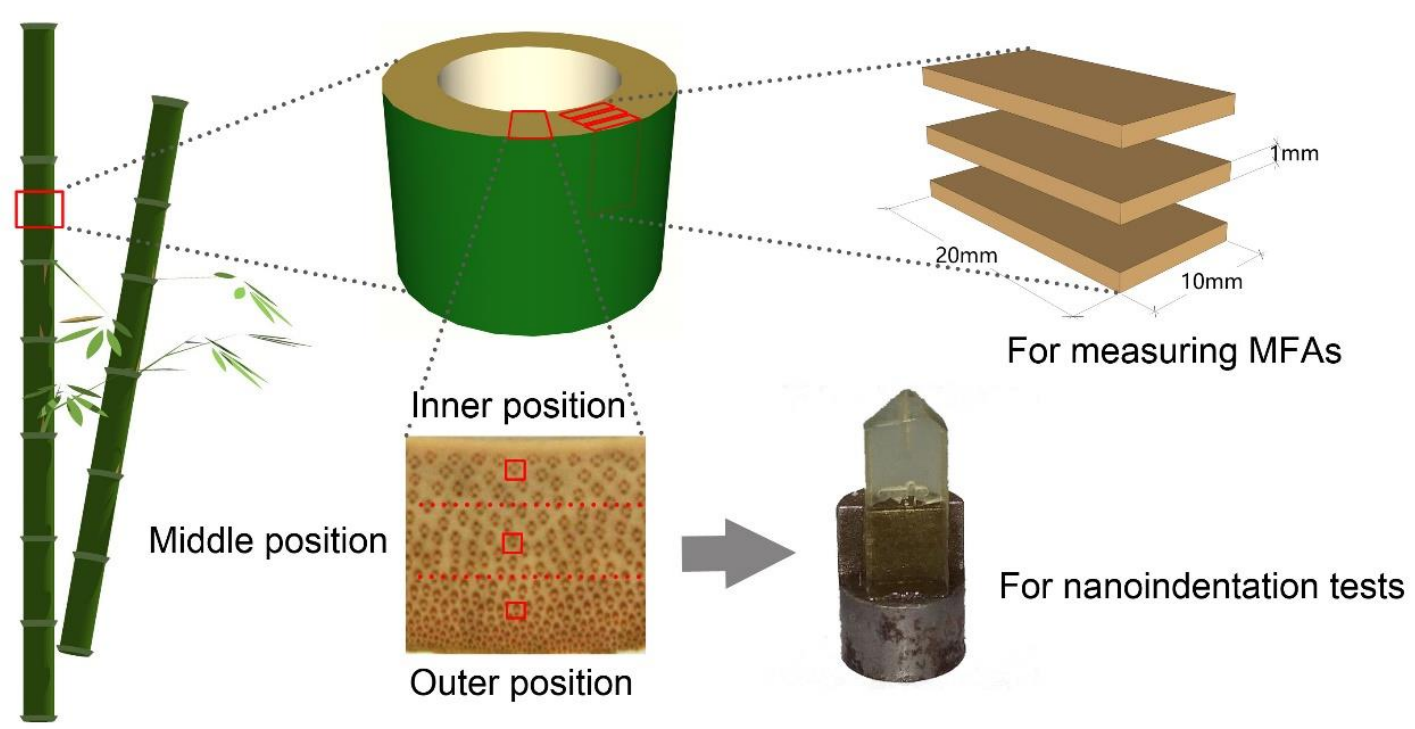

Fig. 1. Schematic of the tested samples and the sampling methods

\section{Nanoindentation Test}

After being removed from the FAA fixative, the bamboo blocks to be tested were put under a stereomicroscope and manually cut using a single-sided blade to obtain 5 to 10 $\mathrm{mm}$ of the vascular bundle. Different concentration gradients of alcohol solutions $(50 \%$, $70 \%, 90 \%, 95 \%$, and 100\%) were used to dehydrate the samples. They were then impregnated with different concentration gradients of Spurr resin (the ratios of alcohol to resin were 2 to 1,1 to 1 , and 0 to 1 ). All processed vascular bundles were embedded with Spurr's resin and then vacuum packed for $0.5 \mathrm{~h}$. After being kept in at $70{ }^{\circ} \mathrm{C}$ in an oven for $8 \mathrm{~h}$, the samples were placed in a desiccator for 2 to 4 days. The embedded samples were loaded into an ultra-microtome sample holder and sectioned into a pyramid shape. A glass knife and a diamond knife were used in sequence to polish the top section for the nanoindentation test (Fig. 1).

The nanoindentation was performed on the fiber cell wall using a TriboIndenter (Hysitron TI-950, Minneapolis, MN, USA) with a diamond probe to perform constant force scanning imaging at the area of interest. The positioning accuracy error was less than 10 
nm. A Berkovich indenter was used in this test and the curvature radius of the Berkovich tip was less than $100 \mathrm{~nm}$. The entire test process was divided into three stages: loading, load holding, and unloading. The duration of each stage was $5 \mathrm{~s}, 6 \mathrm{~s}$, and $3 \mathrm{~s}$, respectively. The loading speed was $50 \mu \mathrm{N}$ per s and the maximum load was $250 \mu \mathrm{N}$. For each group of samples, approximately 30 data points were recorded. Because the samples underwent elastic and plastic deformation during the indentation tests, the result is a nonlinearity timeload diagram, as shown in Fig. 2a. Figure $2 b$ shows the indentation depth-loading curve and Fig. 3 shows the topography before and after the indentation.
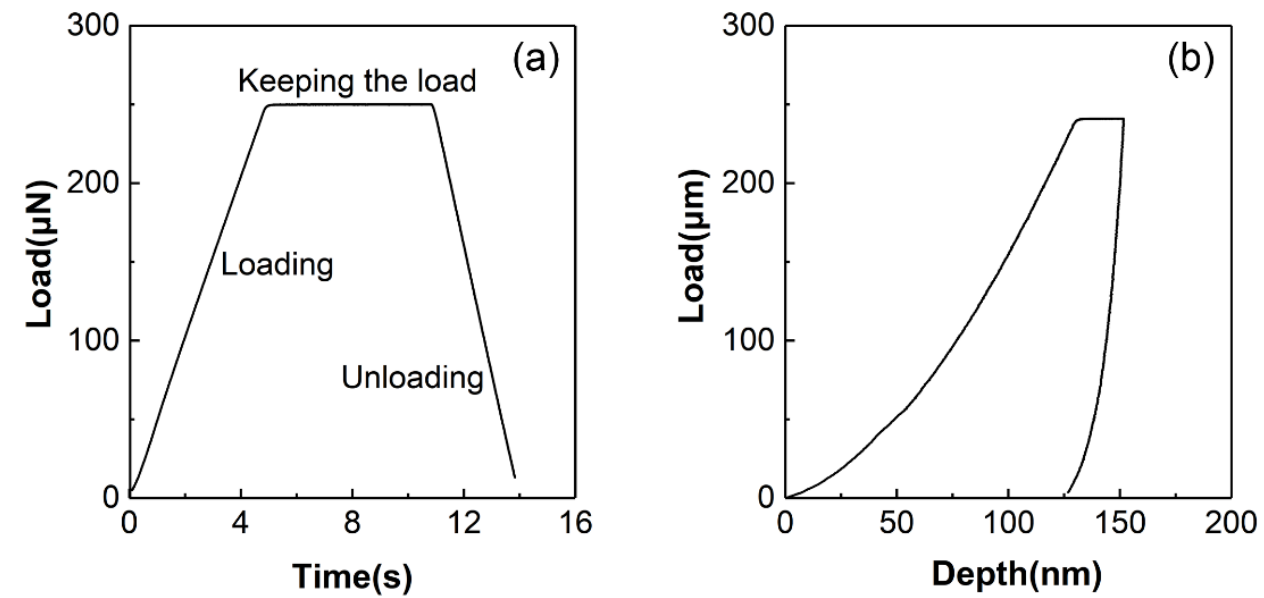

Fig. 2. Loading curve: (a) time-loading curve; (b) indentation depth-loading curve
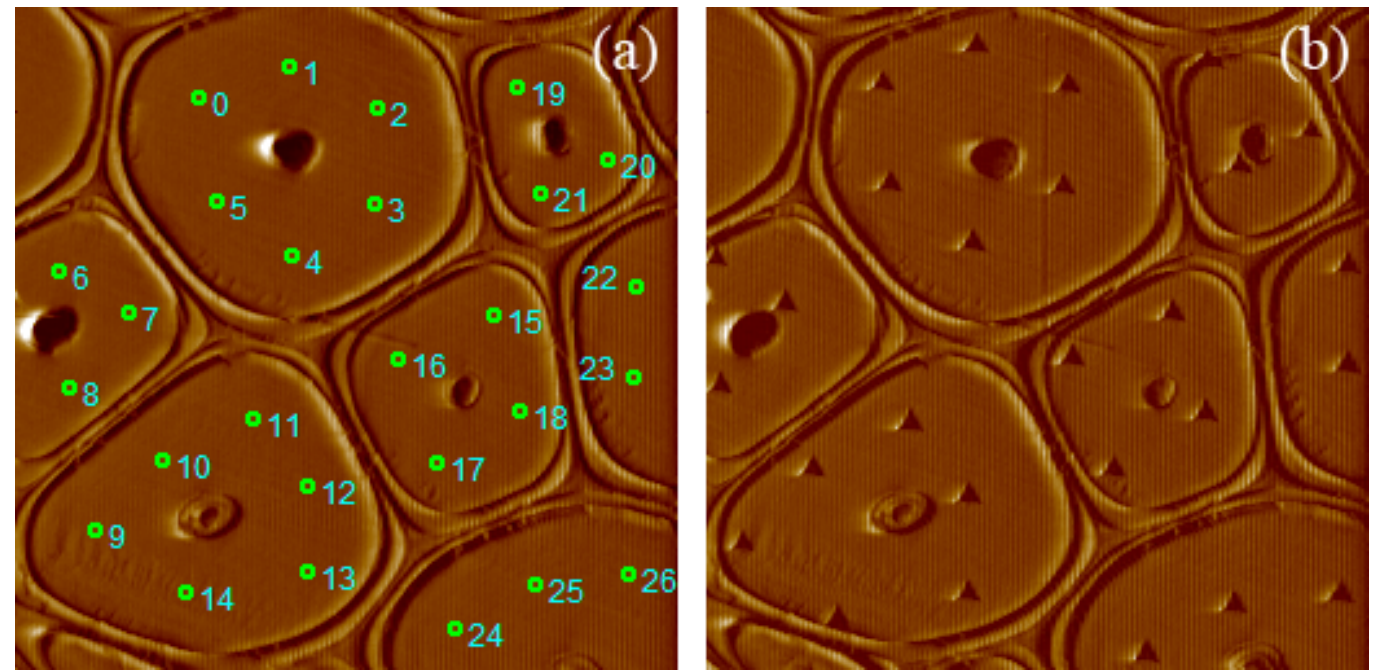

Fig. 3. Scanning images of the cell walls before (a) and after (b) nanoindentation tests

The NI modulus and hardness of the sample were calculated according to the Oliver-Plarr theory, and the calculation formulas were as follows in Eq. 1 and 2,

$$
\begin{aligned}
& 1 \div E_{r}=\left[\left(1-v^{2}\right) \div E\right]-\left[\left(1-v_{i}^{2}\right) \div E_{i}\right] \\
& H=F_{\text {max }} \div A
\end{aligned}
$$

where $E_{r}$ is the reduced modulus (occurred in both the tested sample and the indenter throughout the system), $E$ and $v$ are the elastic modulus and Poisson's ratio of the sample, 
respectively, and $E_{i}$ and $v_{i}$ denote the elasticity modulus and Poisson's ratio of the indenter, respectively. For the spurr resin, $v$ is equal to 0.3. For the Berkovich probe used in the test, $E_{i}$ is equal to $1141 \mathrm{GPa}$ and $v_{i}$ is equal to 0.07 . The parameters $H, F_{\max }$, and $A$ are the NI hardness, the maximum load, and the projected area of the contact surface, respectively. $F_{\max }$ is equal to $250 \mu \mathrm{N}$. The value of $E_{r}$ can be computed according to Eq. 3,

$$
E_{r}=(\sqrt{ } \pi \div 2 \beta) \times(S \div \sqrt{ } A)
$$

where $\beta$ stands for correlation constant of the indenter and its value is 1.034 for a Berkovich indenter. $S$ is the slope of the $50 \%$ to $95 \%$ unloading curve.

\section{MFA Measurement}

For the MFA measurement, bamboo blocks of $20(\mathrm{~L})$ by $10(\mathrm{~T})$ by $t(\mathrm{R}) \mathrm{mm}^{3}$ were cut at the central part at the $6^{\text {th }}, 12^{\text {th }}$, and $18^{\text {th }}$ internode from bamboo culms of different ages ( 1 to 3 years old). Then, the bamboo blocks were processed into small slices of 20 (L) by $10(\mathrm{~T})$ by $1(\mathrm{R}) \mathrm{mm}^{3}$ from the outer to inner of the culm for the age, longitudinal, and radial variations specimens. To make the experimental data as accurate as possible, the sample used to measure the MFA was collected in the same part of the bamboo culms as that of the samples for nanoindentation tests (Table 1 and Fig. 1). All sample pieces were fully processed so that the test surface was smooth and flat. All samples were also carefully numbered for testing.

The MFA was measured using an X-ray diffractometer (Philips X'Pert Pro, Amsterdam, Netherlands). The tube voltage and tube current of the scan test were set to 40 $\mathrm{KV}$ and $40 \mathrm{~mA}$, respectively and the step was $1^{\circ}$. The sample scan range was 0 to $360^{\circ}$. The raw data of the Phi scan intensity was imported into Origin 2017 for single peak fitting and the MFA was calculated by using the 0.6T method (Wang et al. 2016).

\section{RESULTS AND DISCUSSION}

\section{Influence of Different Bamboo Ages on the Mechanical Properties of the Fiber Cell Wall}

During in situ imaging of nanoindentation, the horizontal displacement of the probe is always inevitable. When the indentation point displaces to the cell corner or cell lumen, the measured value is much smaller, and therefore it cannot accurately represent the true mechanical value of the cell wall (Bourmaud and Baley 2012; Wagner et al. 2014). These abnormal mechanical data are detected using a variety of statistical methods. Boxplots not only visually describe the distribution of data and determine the normality of the data, but they also detect abnormal mechanical data (Krzywinski and Altman 2014). Therefore, boxplots were used to detect and reject the outliers of the raw data (Fig. 4), making the data more like the true values. Therefore, it made the measured mechanical properties of the fiber cell wall more reliable. The mean and standard deviation of mechanical properties of the cell wall in different ages and positions are shown in Table 2. Abnormal values were removed. Using SPSS 20.0 software, one-way analysis of variance (ANOVA) was conducted to analyze the NI modulus and hardness of the fiber cell wall of different ages and positions in which bamboo age, radial, and longitudinal positions were considered as factors. The NI modulus and hardness were the dependent variables. The analysis results are shown in Table 3. 


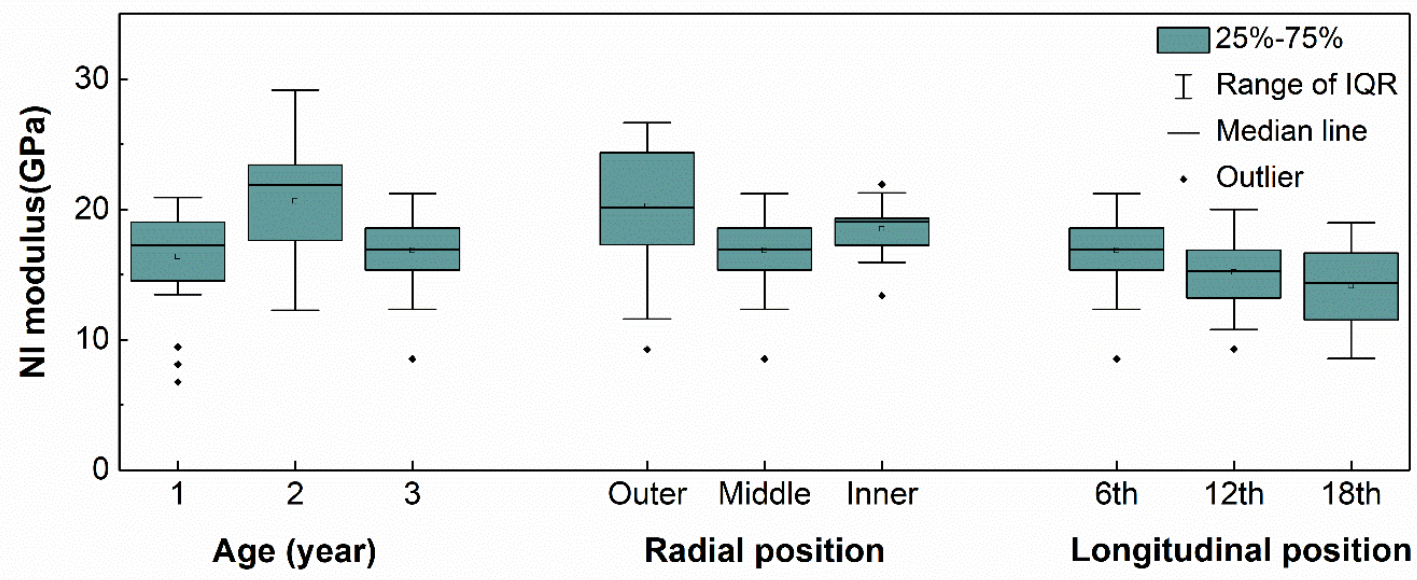

Fig. 4. Boxplot method used to detect outliers (IQR means inter-quartile range)

Table 2. Average Values and Standard Deviation of Cell Wall Mechanical Properties of Different Bamboo Ages and Positions

\begin{tabular}{|c|c|c|c|}
\hline \multicolumn{2}{|c|}{ Influential Factors } & NI Modulus (GPa) & NI Hardness (MPa) \\
\hline \multirow{3}{*}{ Age (years) } & 1 & $17.39 \pm 2.18$ & $412.97 \pm 85.31$ \\
\cline { 2 - 4 } & 2 & $20.10 \pm 3.63$ & $532.26 \pm 76.77$ \\
\cline { 2 - 4 } & 3 & $17.18 \pm 2.43$ & $459.36 \pm 84.22$ \\
\hline \multirow{2}{*}{$\begin{array}{c}\text { Radial } \\
\text { position }\end{array}$} & Outer & $20.19 \pm 4.07$ & $536.50 \pm 84.15$ \\
\cline { 2 - 4 } & Middle & $17.18 \pm 2.43$ & $459.36 \pm 84.22$ \\
\cline { 2 - 4 } & Inner & $18.78 \pm 1.48$ & $497.73 \pm 49.28$ \\
\hline \multirow{2}{*}{$\begin{array}{c}\text { Longitudinal } \\
\text { position }\end{array}$} & 6th & $17.18 \pm 2.43$ & $459.36 \pm 84.22$ \\
\cline { 2 - 4 } & 12 th & $15.38 \pm 2.32$ & $426.02 \pm 59.05$ \\
\cline { 2 - 4 } & 18 th & $14.14 \pm 2.89$ & $488.73 \pm 73.49$ \\
\hline
\end{tabular}

Table 3. ANOVA of Cell Wall Mechanical Properties

\begin{tabular}{|c|c|c|c|c|c|c|}
\hline $\begin{array}{c}\text { Influential } \\
\text { factors }\end{array}$ & Indexes & Sum of squares & DF & Mean square & $\mathrm{F}$ & Sig. \\
\hline \multirow{2}{*}{ Age } & $\mathrm{NI}$ modulus & 152.080 & 2 & 76.040 & 8.946 & $0.000^{*}$ \\
\cline { 2 - 7 } & $\mathrm{NI}$ hardness & 200374.680 & 2 & 100187.340 & 14.383 & $0.000^{*}$ \\
\hline \multirow{2}{*}{$\begin{array}{c}\text { Radial } \\
\text { position }\end{array}$} & $\mathrm{NI}$ modulus & 103.087 & 2 & 51.543 & 6.122 & $0.004^{*}$ \\
\cline { 2 - 7 } & $\mathrm{NI}$ hardness & 66925.150 & 2 & 33462.575 & 5.520 & $0.006^{*}$ \\
\hline $\begin{array}{c}\text { Longitudinal } \\
\text { position }\end{array}$ & $\mathrm{NI}$ modulus & 133.435 & 2 & 66.717 & 9.823 & $0.000^{*}$ \\
\cline { 2 - 7 } & $\mathrm{NI}$ hardness & 61039.155 & 2 & 30519.578 & 5.620 & $0.005^{*}$ \\
\hline
\end{tabular}

The NI modulus and hardness of different aged B. pervariabilis culms are shown in Table 2. Specifically, with the increase of bamboo age, the NI modulus and hardness of B. pervariabilis showed a tendency to decrease after increasing. The fiber cell walls of 2year-old bamboo culms had the highest NI modulus and hardness, followed by the 3-yearold bamboo, and then the 1-year-old bamboo (Table 2). This variation is likely due to differences in soil fertility, the climate of a certain year, and individual variations (Komuraiah et al. 2014; Abdul Khalil et al. 2015). The results from the ANOVA indicate that the NI modulus and hardness of the fiber cell walls are influenced by bamboo ages significantly $(\mathrm{P}<0.05)$ (Table 3), which is inconsistent with a number of previous studies (Huang et al. 2016; Yu et al. 2011; Yang et al. 2014). Yang et al. (2014) tested the mechanical properties of fiber cell walls of 2 to 5-year-old Dendrocalamus farinosus 
culms, and the results showed that the bamboo age had a highly significant impact on NI modulus $(\mathrm{P}<0.01)$ but had significant effect on NI hardness $(\mathrm{P}<0.05)$. The cell wall mechanical properties are closely related to the degree of lignification in culms. During the process of lignification, bamboo continuously accumulates fibers and parenchyma tissue, and the growth is completed in one growing season. The bamboo cells are no longer lignified after the growing season, and the mechanical properties of the cells become stable (Itoh 1990; Depuydt et al. 2019). In terms of the mechanical properties of the fiber cell wall of 1-, 2-, and 3-year-old B. pervariabilis culms, their NI modulus and hardness stabilized, which is consistent with other studies. Yu et al. (2011) studied the mechanical properties of the fiber wall of 6-month-old, 2- and 4-year-old moso bamboo by using in situ imaging nanoindentation. Yu et al. (2011) found that the fibers of bamboo culms of different ages have similar mechanical properties. Huang et al. (2016) evaluated the mechanical properties of the fiber cells of young moso bamboo $(1,2,6,18$, and 36 months old). The results showed that the NI modulus did not change remarkably with the increase in bamboo age. The NI hardness obviously increased in 6-month-old bamboo culms and stabilized after 6 months, indicating that the NI hardness of bamboo fiber may only increase during the first 6 months.

\section{Influence of Different Bamboo Positions on the Mechanical Properties of the Fiber Cell Walls}

Bamboo is an anisotropic material. Therefore, the mechanical properties will be variable in different positions of the walls and different heights of the bamboo culms. From the outside to the inside, bamboo walls may be divided radially into three parts: the inner position, middle position, and outer position. The cell wall NI modulus and hardness variations of these three parts are shown in Table 2. In this research, the average NI modulus and hardness were $18.7 \mathrm{GPa}$ and $498 \mathrm{MPa}$, respectively. The NI modulus and hardness first drop and then rebound slightly from the outside to the inside. In the vertical direction of the bamboo culm, the average NI modulus and hardness of the $6^{\text {th }}, 12^{\text {th }}$, and $18^{\text {th }}$ internode fiber cell walls from the 3 -year-old bamboo were $15.6 \mathrm{GPa}$ and $458 \mathrm{MPa}$, respectively. As the height of the bamboo culm increased, the NI modulus showed a decreasing trend. The NI hardness visibly increased for the top position when compared to the base and middle parts (Table 2). The results of the variance analysis showed that the radial and longitudinal positions had significant effects on the NI modulus and hardness ( $\mathrm{P}$ $<0.05$ ) (Table 3). This result contrasts with previously published research. Yang et al. (2014) studied the cell wall mechanical properties of $D$. farinosus and found no significant difference in the NI modulus and hardness among the inner, middle, and outer positions of the culms ( $\mathrm{P}>0.05)$. Only minor longitudinal variations were found. This indicates that there are different variations in the mechanical properties of the fiber wall of different bamboo species.

The variations of micromechanical properties observed in different positions of the bamboo culms were attributed to the fact that bamboo itself is a complex and non-uniform material, and its structure and composition distribution are heterogeneous. The volume fraction of vascular bundles enlarges radially outward from the bamboo culm and the density also showed a gradient increase. As a result, the density of the outer culm of bamboo is greater than the inner, which is in agreement with the mechanical property variations of the cell wall in the radial direction (Dixon and Gibson 2014). A previous study has confirmed that the content of the chemical components has a significant effect on the mechanical properties of the cell wall $(\mathrm{P}<0.05)$. Additionally, the content of lignin and 
hemicellulose are positively correlated with the cell wall NI modulus and hardness of bamboo (Gindl et al. 2004). Using a combination of physical and chemical methods, Wang et al. (2016) gradually removed the extracts, hemicellulose, and lignin from the cell walls. The authors found that the mechanical properties of the wood cell wall were mainly affected by cellulose, while the lignin affected the NI modulus of the cell wall. Li et al. (2017) used a heat treatment to remove the hemicellulose from bamboo materials and found that the crystallinity and lignin content increased. Li et al. (2017) also found that both the fiber cell wall NI modulus and hardness greatly increased. The chemical composition shows variations between different parts of the bamboo wall. At the cellular level, the lignin content of bamboo fiber is higher than that of the vessel and the lignin content is the lowest in the parenchyma (Lin et al. 2002). The relative content of the main chemical components of the outer is higher than that of the inner of culm (Dixon and Gibson 2014; Wei et al. 2017). The holocellulose content also significantly decreased from the top to the base of culm. However, a previous study showed that the Klason lignin content shows no obvious variation with bamboo maturation ( $\mathrm{Li}$ et al. 2007). Taken together, these differences might be one of the main causes of the variation of mechanical properties in the fiber cell walls.

\section{Relationship between MFA and the Mechanical Properties of Fiber Cell Walls}

The MFA values of $B$. pervariabilis culms of different ages and positions are shown in Fig. 5. The average MFAs of 1, 2, and 3-year-old bamboo were $8.42^{\circ}, 8.33^{\circ}$, and $8.26^{\circ}$, respectively. Older bamboo materials tended to have a smaller MFA (Fig. 5a). This result is consistent with the variation in MFA with age as observed by Liu et al. (2014) in $D$. farinosus culms. The MFAs of 1, 2, and 3-year-old B. pervariabilis culms showed a very small variation. The average difference between the maximum and minimum was only $0.16^{\circ}$. Therefore, during the three years, the MFA of $B$. pervariabilis culms remained stable. For bamboo culms, the MFA gradually increased radially from the outer to the inner and the average values were $8.15^{\circ}, 8.26^{\circ}$, and $8.49^{\circ}$, respectively. Only small changes were observed (Fig. 5b). For the $6^{\text {th }}, 12^{\text {th }}$, and $18^{\text {th }}$ internode, the average MFAs were $8.44^{\circ}$, $8.27^{\circ}$, and $8.19^{\circ}$, respectively. This indicated that in the longitudinal direction, the average MFA decreased with the increasing height of the bamboo culms (Fig. 5c).
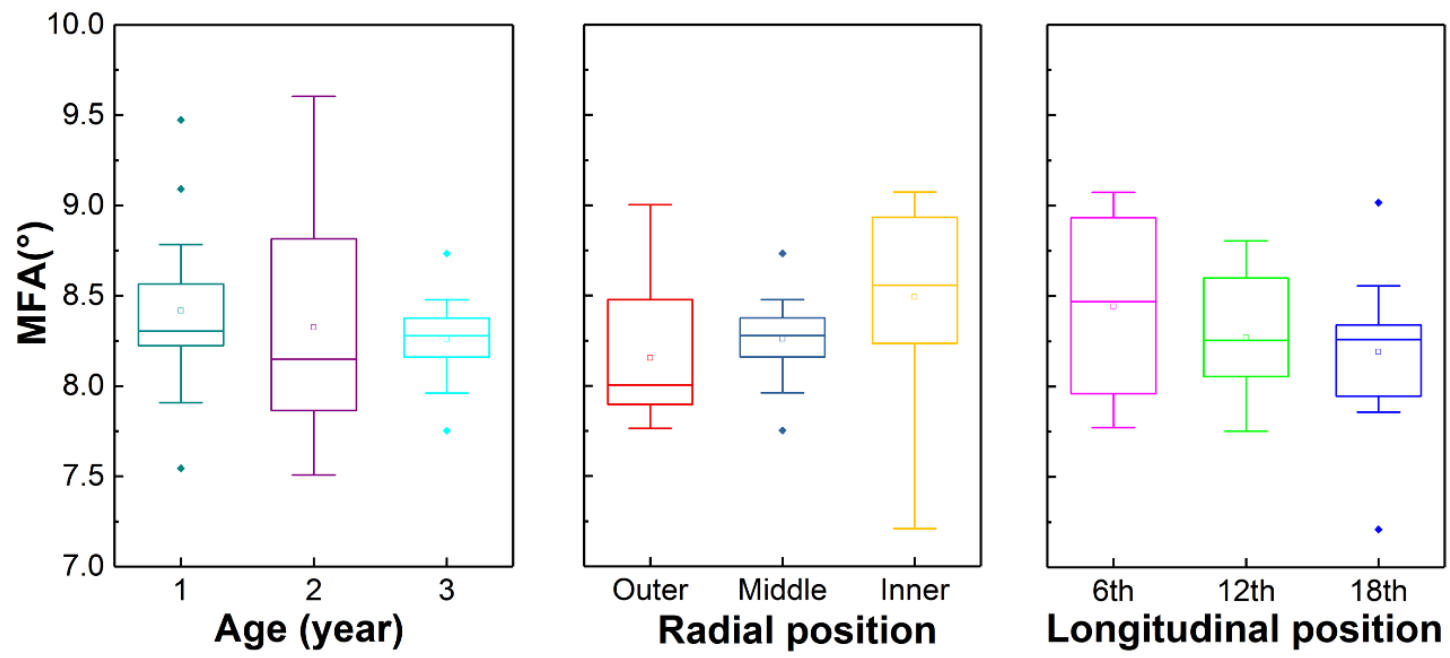

Fig. 5. The variation of MFA with bamboo age (a), radial position (b), and longitudinal position (c) 
Table 4. Correlation Analysis of the MFA and Mechanical Properties of the Fiber Cell Wall of $B$. pervariabilis

\begin{tabular}{|c|c|c|c|c|c|c|}
\hline \multirow{2}{*}{ Items } & \multicolumn{2}{|c|}{ Age } & \multicolumn{2}{c|}{ Radial position } & \multicolumn{2}{c|}{ Longitudinal position } \\
\cline { 2 - 7 } & $\begin{array}{c}\mathrm{NI} \\
\text { modulus }\end{array}$ & $\begin{array}{c}\mathrm{NI} \\
\text { hardness }\end{array}$ & $\begin{array}{c}\mathrm{NI} \\
\text { modulus }\end{array}$ & $\begin{array}{c}\mathrm{NI} \\
\text { hardness }\end{array}$ & $\begin{array}{c}\mathrm{NI} \\
\text { modulus }\end{array}$ & $\begin{array}{c}\mathrm{NI} \\
\text { hardness }\end{array}$ \\
\hline MFA & -0.008 & -0.451 & -0.282 & -0.320 & 0.995 & -0.278 \\
\hline Sig. & 0.995 & 0.702 & 0.818 & 0.793 & 0.063 & 0.820 \\
\hline
\end{tabular}

MFA is an important factor affecting the mechanical properties of bamboo and wood (Reiterer et al. 1999). In fiber cell wall mechanics, the MFA has a particularly remarkable effect on the cell wall NI modulus, but it has little effect on the NI hardness. To study the correlation between these two factors, the bivariate correlation analysis was conducted using SPSS software on the average values. Two-sided tests were also conducted to check the significance of the correlation (Table 4). The Pearson correlation analysis showed that the MFA was negatively correlated with the fiber cell wall mechanical properties (Table 4), which is consistent with the results of many previous studies (Liu 2008; Konnerth et al. 2009; Jäger et al. 2011). However, in this research, the correlation was not significant $(\mathrm{P}>0.05)$. It is worth noting that the MFA in the longitudinal direction was positively correlated with the NI modulus. This further shows that the mechanical properties of the bamboo fiber cell wall are synergistically affected by various factors. However, it is difficult to verify whether the MFA is the most important factor in this study.

\section{CONCLUSIONS}

1. The average nanoindentation (NI) modulus and hardness of B. pervariabilis fiber cell walls were $17.5 \mathrm{GPa}$ and $475 \mathrm{MPa}$, respectively. The average MFA was $8.31^{\circ}$.

2. With increasing age in the bamboo culms, both the NI modulus and hardness showed an initial increasing trend, followed by a decreasing trend. In the radial direction, the NI modulus and hardness of the middle position were the lowest, while the NI modulus and hardness of the outer position were the greatest. In the longitudinal direction, the NI modulus of the fiber cell wall decreased with height, but the upper position of the bamboo culm had the highest NI hardness.

3. There was no significant correlation between the mechanics of the fiber cell wall and the MFA. The analysis of the factors affecting the NI modulus and hardness of bamboo fiber further demonstrated that the mechanical properties of fiber cell walls are synergistically affected by various factors.

\section{ACKNOWLEDGMENTS}

The authors are grateful for the support of the National Natural Science Foundation of China (No. 31670565), the National Science and Technology Support Plan (No. 2015BAD04B03), the National Key Research \& Development Program (No. 2016YFD0600904). 


\section{REFERENCES CITED}

Abdul Khalil, H. P. S., Hossain, M. S., Rosamah, E., Azli, N. A., Saddon, N., Davoudpoura, Y., Islam, M. N., and Dungani, R. (2015). "The role of soil properties and its interaction towards quality plant fiber: A review," Renew. Sust. Energ. Rev. 43, 1006-1015. DOI: 10.1016/j.rser.2014.11.099

Bourmaud, A., and Baley, C. (2012). "Nanoindentation contribution to mechanical characterization of vegetal fibers," Compos. Part B Eng. 43(7), 2861-2866. DOI: 10.1016/j.compositesb.2012.04.050

Bourmaud, A., Morvan, C., Bouali, A., Placet, V., Perré, P., and Baley, C. (2013). "Relationships between micro-fibrillar angle, mechanical properties and biochemical composition of flax fibers," Ind. Crop. Prod. 44, 343-351. DOI: 10.1016/j.indcrop.2012.11.031

Castanet, E., Li, Q. X., Dumée, L. F., Garvey, C., Rajkhowa, R., Zhang, J., Rolfe, B., and Magniez, K. (2016). "Structure-property relationships of elementary bamboo fibers," Cellulose 23(6), 3521-3534. DOI: 10.1007/s10570-016-1078-8

Depuydt, D. E. C., Sweygers, N., Appels, L., Ivens, J., and Vuure, A. W. (2019). "Bamboo fibres sourced from three global locations: A microstructural, mechanical and chemical composition study," J. Reinf. Plast. Comp. 38(9), 397-412. DOI: $10.1177 / 0731684419828532$

Dixon, P. G., and Gibson, L. J. (2014). "The structure and mechanics of moso bamboo material,” J. R. Soc. Interface. 11, 20140321. DOI: 10.1098/rsif.2014.0321

Gindl, W., Gupta, H. S., Schöberl, T., Lichtenegger, H. C., and Fratzl, P. (2004). "Mechanical properties of spruce wood cell walls by nanoindentation," Appl. Phys. A. 79(8), 2069-2073. DOI: 10.1007/s00339-004-2864-y

Gupta, D. K., and Singh, R. C. (2018). "An experimental evaluation of mechanical properties of bamboo fiber reinforced concrete," IRJET 5(8), 1382-1385. DOI:

Hu, K. L., Huang, Y. H., Fei, B. H., Yao, C. L., and Zhao, C. (2017). "Investigation of the multilayered structure and microfibril angle of different types of bamboo cell walls at the micro/nano level using a LC-PolScope imaging system," Cellulos. 24(11), 1-15. DOI: 10.1007/s10570-017-1447-y

Huang, Y. H., and Fei, B. H. (2017). "Comparison of the mechanical characteristics of fibers and cell walls from moso bamboo and wood," BioResources 12(4), 8230-8239. DOI: 10.15376/biores.12.4.8230-8239

Huang, Y. H., Fei, B. H., Wei, P. L., and Zhao, C. (2016). "Mechanical properties of bamboo fiber cell walls during the culm development by nanoindentation," Ind. Crop. Prod. 92, 102-108. DOI: 10.1016/j.indcrop.2016.07.037

Itoh, T. (1990). "Lignification of bamboo (Phyllostachys heterocycla Mitf.) during its growth," Holzforschung 44(3), 191-200. DOI: 10.1515/hfsg.1990.44.3.191

Jäger, A., Bader, T., Hofstetter, K., and Eberhardsteiner, J. (2011). "The relation between indentation modulus, microfibril angle, and elastic properties of wood cell walls," Compos. Part A Appl. S. 42(6), 677-685. DOI: 10.1016/j.compositesa.2011.02.007

Komuraiah, A., Kumar, N. S., and Prasad, B. D. (2014). "Chemical composition of natural fibers and its influence on their mechanical properties," Mech. Compos. Mater. 50(3), 359-376. DOI: 10.1007/s11029-014-9422-2

Konnerth, J., Gierlinger, N., Keckes, J., and Gindl, W. (2009). “Actual versus apparent within cell wall variability of nanoindentation results from wood cell walls related to cellulose microfibril angle," J. Mater. Sci. 44(16), 4399-4406. DOI: 10.1007/s10853- 
009-3665-7

Krauss, A., Moliński W., Kúdela J., and Čunderlik I. (2011). "Differences in the mechanical properties of early and latewood within individual annual rings in dominant pine tree (Pinus sylvestris L.)," Wood Research 55(2), 7-12.

Krzywinski, M., and Altman, N. (2014). "Visualizing samples with box plots: use box plots to illustrate the spread and differences of samples," Nat. Methods. 11(2), 119121. DOI: $10.1038 /$ nmeth.2813

Kumar, N., Mireja, S., Khandelwal, V., Arun, B., and Manik, G. (2017). "Light-weight high-strength hollow glass microspheres and bamboo fiber-based hybrid polypropylene composite: A strength analysis and morphological study," Compos. Part B Eng. 109, 277-285. DOI: 10.1016/j.compositesb.2016.10.052

Li, X. B., Shupe, T. F., Peter, G. F., Hse, C. Y., and Eberhard, T. L. (2007). "Chemical changes with maturation of the bamboo species Phyllostachys pubescens," J. Trop. For. Sci. 19(1), 6-12.

Li, Y. J., Huang, C. J., Wang, L., Wang, S. Q., and Wang, X. Z. (2017). "The effects of thermal treatment on the nanomechanical behavior of bamboo (Phyllostachys pubescens Mazel ex H. de Lehaie) cell walls observed by nanoindentation, XRD, and wet chemistry," Holzforschung 71(2), 129-135. DOI: 10.1515/hf-2016-0124

Lin, J. X., He, X. Q., Hu, Y. X., Kuang, T., and Ceulemans, R. (2002). "Lignification and lignin heterogeneity for various age classes of bamboo (Phyllostachys pubescens) stems," Physiol. Plantarum. 114(2), 296-302. DOI: 10.1034/j.13993054.2002.1140216.x

Liu, B. (2008). Formation of Cell Wall in Developmental Culms of Phyllostachys pubescens, Dissertation, Chinese Academy of Forestry, China.

Liu, X. E., Yang, X., Yang, S. M., Tian, G. L., and Shang, L. L. (2014). "Variation of microfibril angle in Dendrocalamus farinosus analyzed based on X-ray diffraction spectrum and its effect on tensile properties," Spectrosc. Spect. Anal. 34(6), 16981701. DOI: 10.3964/j.issn.1000-0593(2014)06-1698-04

Lo, T. Y., Cui, H. Z., and Leung, H. C. (2004). "The effect of fiber density on strength capacity of bamboo," Mater. Let. 58(21), 2595-2598. DOI: 10.1016/j.matlet.2004.03.029

Meng, Y. J., Wang, S. Q., Cai, Z. Y., Young, T. M., Du, G. B., and Li, Y. J. (2013). “A novel sample preparation method to avoid influence of embedding medium during nano-indentation," Appl. Phys. A. 110(2), 361-369. DOI: 10.1007/s00339-012-7123-z

Reiterer, A., Lichtenegger, H., Tschegg, S., and Fratzl, P. (1999). "Experimental evidence for a mechanical function of the cellulose microfibril angle in wood cell walls," Philos. Mag. A. 79(9), 2173-2184. DOI: 10.1080/01418619908210415

Ren, D., Yu, Z. X., Zhang, X. X., Wang, H. K., Wang, H., and Yu, Y. (2017). "Quantitative characterization of the interface between bamboo fiber and polypropylene with pull-out test and nanomechanical imaging," J. Mater. Sci. 52(3), 1296-1307. DOI: $10.1007 / \mathrm{s} 10853-016-0425-3$

Sukmawan, R., Takagi, H., and Nakagaito, A. N. (2016). "Strength evaluation of crossply green composite laminates reinforced by bamboo fiber," Compos. Part B Eng. 84, 9-16. DOI: 10.1016/j.compositesb.2015.08.072

Tian, G. L. (2015). The Main Influence Factors of Bamboo Fiber Mechanical Properties, Dissertation, Chinese Academy of Forestry, China.

Tze, W. T. Y., Wang, S., Rials, T. G., Pharr, G. M., and Kelley, S. S. (2007).

"Nanoindentation of wood cell walls: Continuous stiffness and hardness 
measurements," Compos. Part A-Appl. S. 38(3), 945-953. DOI:

10.1016/j.compositesa.2006.06.018

Wagner, L., Bader, T. K., and De, Borst, K. (2014). "Nanoindentation of wood cell walls: effects of sample preparation and indentation protocol," J. Mater. Sci. 49(1), 94-102. DOI: $10.1007 / \mathrm{s} 10853-013-7680-3$

Wang, X. Q., Ren, H. Q., Zhang, B., Fei, B. H., and Burgert, L. (2012). “Cell wall structure and formation of maturing fibres of moso bamboo (Phyllostachys pubescens) increase buckling resistance," J. R. Soc. Interface 9(70), 988-996. DOI: 10.1098/rsif.2011.0462

Wang, X. Z., Li, Y. J., Deng, Y. H., Yu, W. W., Xie, X. Q., and Wang, S. Q. (2016). "Contributions of basic chemical components to the mechanical behavior of wood fiber cell walls as evaluated by nanoindentation," BioResources 11(3), 6026-6039. DOI: 10.15376/biores.11.3.6026-6039

Wang, X., Keplinger, T., Gierlinger, N. and Burgert, I. (2014). "Plant material features responsible for bamboo's excellent mechanical performance: A comparison of tensile properties of bamboo and spruce at the tissue, fibre and cell wall levels," Ann. Bot. 114(8), 1627-1635. DOI: 10.1093/aob/mcu180

Wang, Y. R., Liu, C. R., Zhao, R. J., Jessica, M. C., Rials, T., and Wang, S. Q. (2016). "Anatomical characteristics, microfibril angle and micromechanical properties of cottonwood (Populus deltoides) and its hybrids," Biomass. Bioenerg. 93, 72-77. DOI: 10.1016/j.biombioe.2016.06.011

Wei, P. L., Ma, J. F., Jiang, Z. H., Liu, R., An, X., and Fei, B. H. (2017). “Chemical constituent distribution within multilayered cell walls of moso bamboo fiber tested by confocal Raman microscopy," Wood Fiber Sci. 49(1), 12-21.

Wimmer, R., Lucas, B. N., Oliver, W. C., and Tsui, T. Y. (1997). "Longitudinal hardness and Young's modulus of spruce tracheid secondary walls using nanoindentation technique," Wood. Sci. Technol. 31(2), 131-141. DOI: 10.1007/BF00705928

Yang, X., Tian, G. L., Shang, L. L., Lv, H. F., Yang, S. M., and Liu, X. E. (2014). "Variation in the cell wall mechanical properties of Dendrocalamus farinosus bamboo by nanoindentation," BioResources 9(2), 2289-2298. DOI: 10.15376/biores.9.2.2289-2298

Yu, Y., Fei, B. H., Zhang, B., and Yu, X. (2007). "Cell-wall mechanical properties of bamboo investigated by in-situ imaging nanoindentation," Wood Fiber Sci. 39(4), 527-535.

Yu, Y., Tian, G. L., Wang, H. K., Fei, B. H., and Wang, G. (2011). "Mechanical characterization of single bamboo fibers with nanoindentation and microtensile technique," Holzforschung 65, 113-119. DOI: 10.1515/hf.2011.009

Zou, L. H., Jin, H., Lu, W. Y., and Li, X. D. (2009). "Nanoscale structural and mechanical characterization of the cell wall of bamboo fibers," Mat. Sci. Eng. C. 29(4), 1375-1379. DOI: 10.1016/j.msec.2008.11.007

Article submitted: February 14, 2020; Peer review completed: May 9, 2020; Revised version received and accepted: May 15, 2020: Published: May 20, 2020.

DOI: $10.15376 /$ biores.15.3.5316-5327 